City University of New York (CUNY)

CUNY Academic Works

\title{
THE NASA MUREP AEROSPACE ACADEMY PROGRAM (MAA): PLAYING A PIVOTAL ROLE IN BRIDGING THE KNOWLEDGE-GAP DURING THE COVID-19 PANDEMIC
}

\author{
Nazrul I. Khandaker \\ cUNY York College \\ Omadevi Singh \\ NASA MUREP Aerospace Academy \\ Sol De Leon \\ NASA MUREP Aerospace Academy \\ Violeta Escandon \\ High School for Construction Trades, Engineering and Architecture \\ Tajriyan Chowdhury \\ Bronx High School for the Sciences
}

See next page for additional authors

\section{How does access to this work benefit you? Let us know!}

More information about this work at: https://academicworks.cuny.edu/yc_pubs/291

Discover additional works at: https://academicworks.cuny.edu

This work is made publicly available by the City University of New York (CUNY).

Contact: AcademicWorks@cuny.edu 


\section{Authors}

Nazrul I. Khandaker, Omadevi Singh, Sol De Leon, Violeta Escandon, Tajriyan Chowdhury, Anthony

Ramnarain, Sahaj Khan, Najina Tojiboeva, Raj Datta, Brian Sukhnandan, Farshad Hosseinie, and Fiorella Guevara 
The COVID-19 pandemic forced all City University of New York CUNY campuses, including York College, to offer virtual learning opportunities to students. NASA MAA, being an outreach STEM program, also fell under the students. NASA MAA, being an outreach STEM program, also fell under
same category and swiftly came-up with a plan to move into DLM. Initial surveys indicated the basic household technology needed to attend virtual sessions and showed complicated situations where parents had multiple children attending the summer 2020 session. To ensure greater participation, computers, iPads, Chromebooks, and cell phones were used. Common platforms. like WebEx and Zoom, were routinely used by our MAA teachers to disseminate online content delivery.

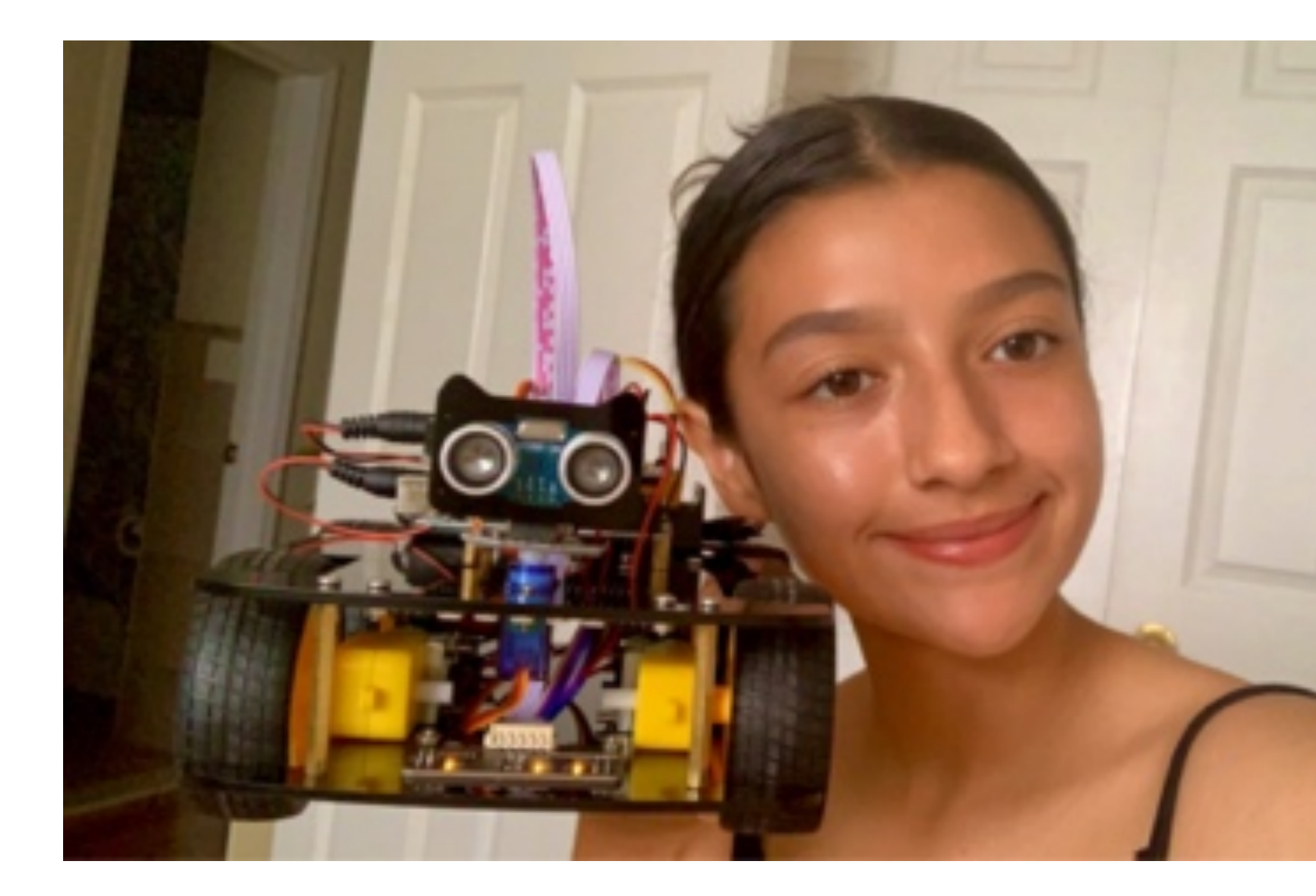

Figure 1: High School student with robot

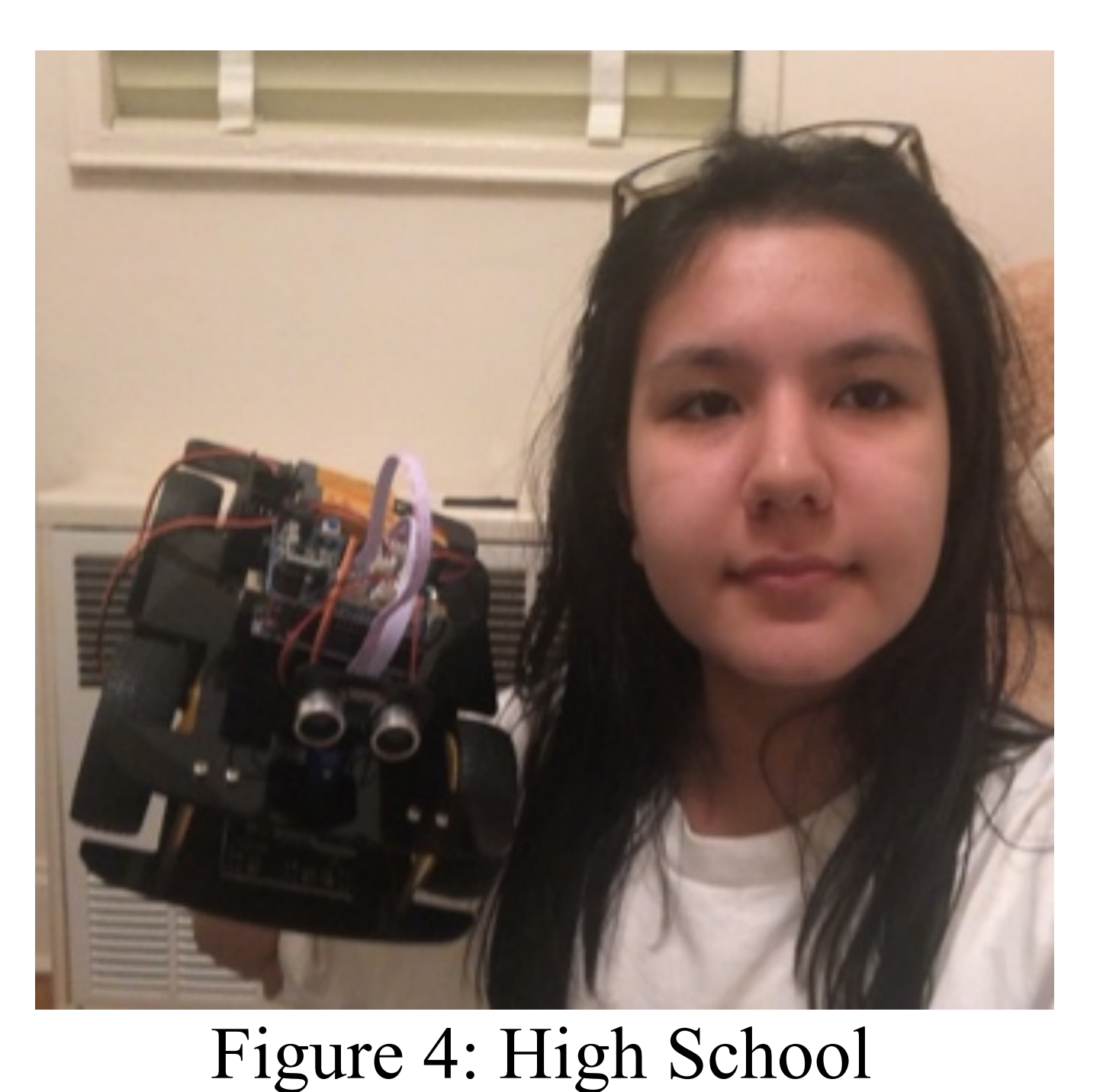

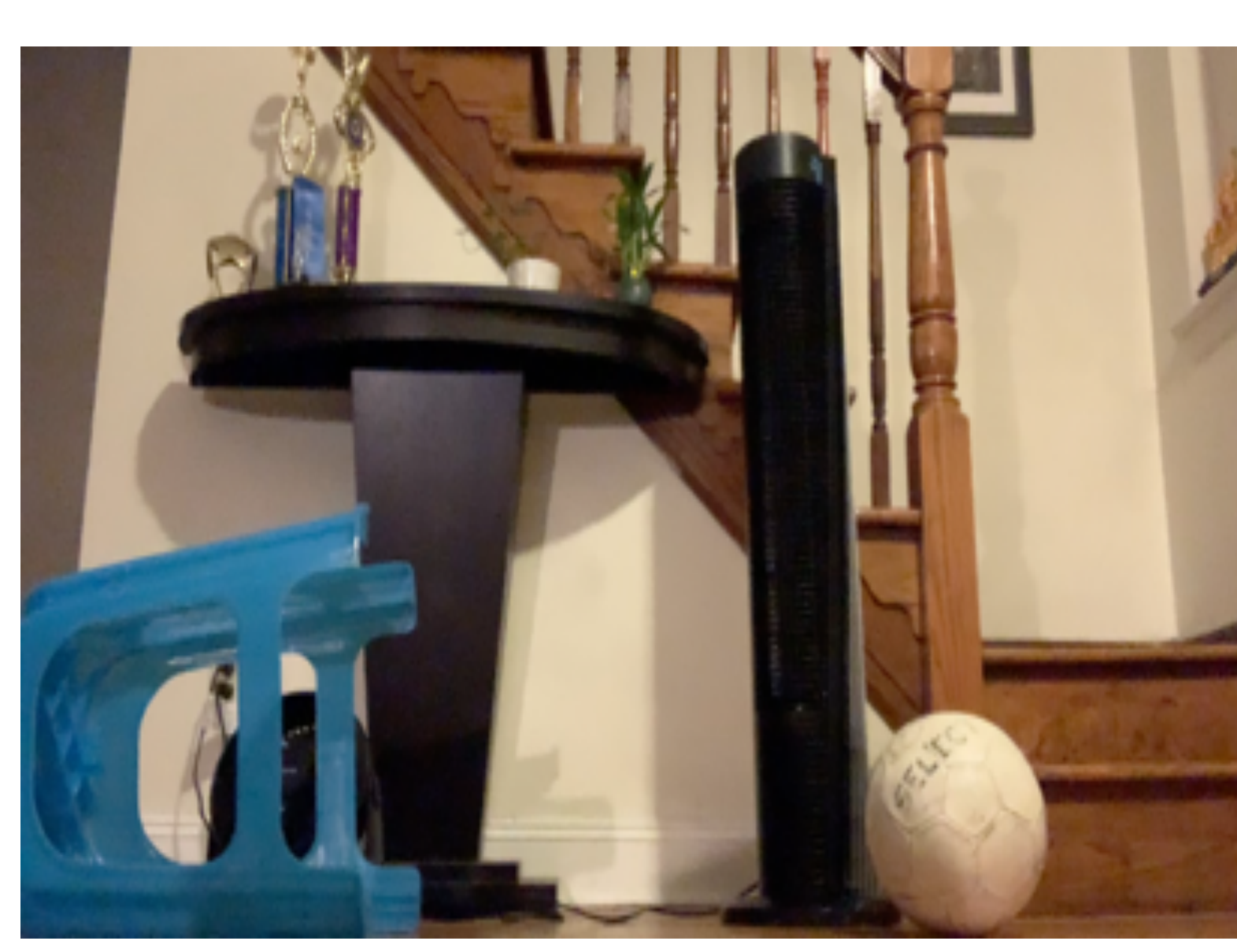

Figure 5: High School student created an obstacle course for their robot
To face the "New Normal" like many of us, MAA staff diligently searched for best practices pertaining to the online delivery of STEM contents to the students through established sources such as NASA, American Museum of Natural History, NASA Educators Online Network (NEON), and JPL (Jet Propulsion Laboratory). Carefully crafted grade-specific lessons and activities on earth's material properties, rocketry, coding (python, raspberry, kahoot) programming, electric circuit building, flight simulation, GPS-supported weather tracking, stargazing, EV3 Mindstorm Lego and robotics, and Martian habitat - suitable in home-based settings - were introduced to the students. With the help of the Family Focus Group (FFG), the traditional classroom environment was brought back to individual homes, where both parents and students collaborated together, sought answers, and completed assignments concerning STEM lessons. Many younger students, particularly in elementary grades, were very excited to see their friends online and exchanging greetings via chat box.

Program Highlights

The program being free is one of its greatest assets, particular for families from lowincome communities who would otherwise not be able to afford such quality STEM program.

York's NASA MAA has become a robust ecosystem that continues to fuel itself, cultivating the interest, participation, and persistence required to broaden STEM participation to become more inclusive of historically under-served, underrepresented youth and communities (comments from the external evaluator)

Figure 2: High Schoo

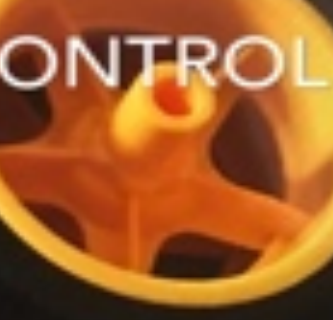

Figure 3: Robots provided to high school students
NASA MAA not only enables students to gain confidence in STEM-related concepts and applications, it creates a positive environment that promotes effective group dynamics, where social skills continue to flourish among the students. Thus, a team-building culture starts right from the beginning of the program - a powerful attribute where students feel comfortable to act, cooperate, respect, and successfully accomplish exercises. It is a gratifying situation, and MAA students and parents sincerely acknowledge such a unique education goal following the NASA Education Mission Directorate. Additional corporate support from AT\&T and ConEdison allows the NASA MUREP Program to engage high school students in research activities.

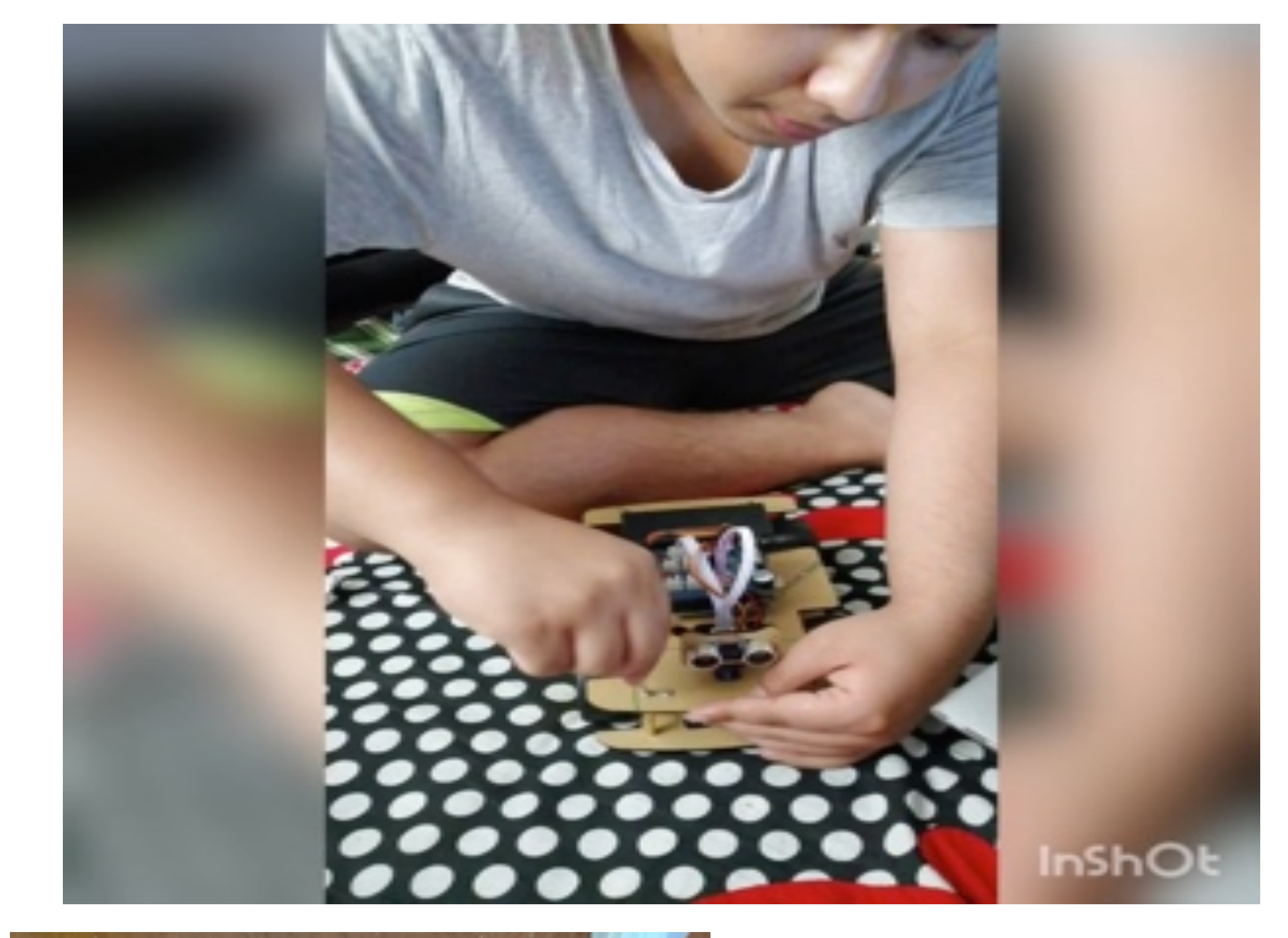

Figure 8: High Schoo student working on robot
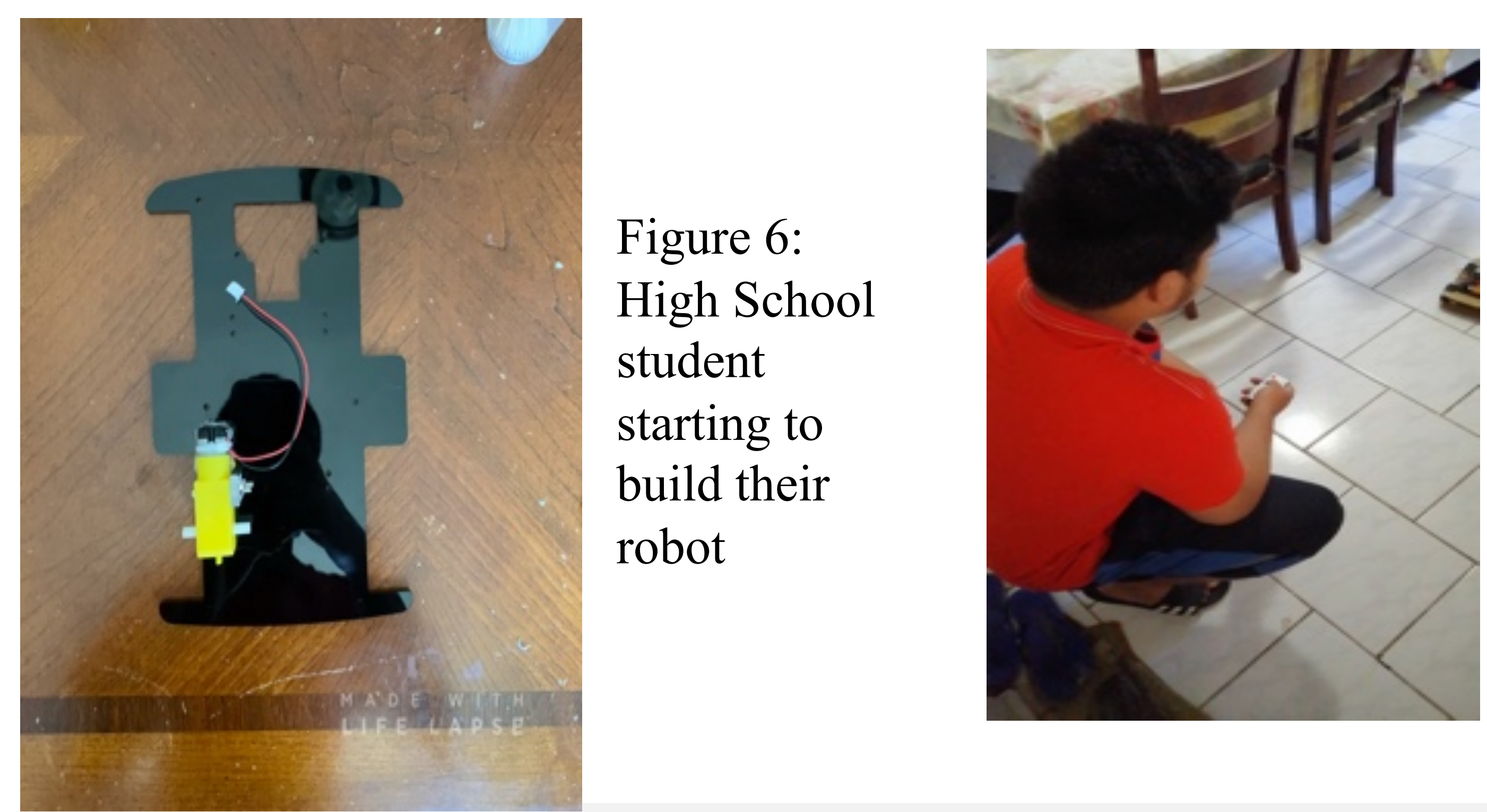
High
School student testing his robot robot

vered by controls if you define slides 